\title{
A genome scan for quantitative trait loci affecting body conformation traits in Spanish Churra dairy sheep
}

\author{
B. Gutiérrez-Gil, L. Alvarez, L. F. de la Fuente, J. P. Sanchez, F. San Primitivo, and J. J. Arranz ${ }^{1}$ \\ Departamento de Producción Animal, Facultad de Veterinaria, Universidad de León, 24071, León, Spain
}

\section{ABSTRACT}

A genome scan for chromosomal regions influencing body conformation traits was conducted for a population of Spanish Churra dairy sheep following a daughter design. A total of 739 ewes from 11 half-sib sire families were included in the study. The ewes were scored for the 5 linear traits used in the breeding scheme of the Churra breed to assess body conformation: stature, rear legs-rear view, foot angle, rump width, and general appearance. All the animals, including the 11 sires, were genotyped for 181 microsatellite markers evenly distributed across the 26 sheep autosomes. Using the yield deviations of the raw scores adjusted for fixed factors as phenotypic measurements, a quantitative trait loci (QTL) analysis was performed on the basis of a multi-marker regression method. Seven suggestive QTL were identified on chromosomes Ovis aries (OAR)2, OAR5, OAR16, OAR23, and OAR26, but none reached a genome-wise significance level. Putative QTL were identified for all of the traits analyzed, except for general appearance score. The suggestive QTL showing the highest test statistic influenced rear legs-rear view and was localized on OAR16, close to the growth hormone receptor coding gene, GHR. Some of the putative linkage associations reported here are consistent with previously reported QTL in cattle for similar traits. To the best of our knowledge, this study provides the first report of QTL for body conformation traits in dairy sheep; further studies will be needed to confirm and redefine the linkage associations reported herein. It is expected that future genome-wide association analyses of larger families will help identify genes underlying these putative genetic effects and provide useful markers for marker-assisted selection of such functional traits.

Key words: dairy sheep, functional trait, body conformation, quantitative trait loci

\footnotetext{
Received November 22, 2010.

Accepted April 19, 2011.

${ }^{1}$ Corresponding author: jjarrs@unileon.es
}

\section{INTRODUCTION}

Functional traits are of importance to dairy sheep production systems because they are related to the animal's longevity and welfare; consequently, they are relevant to overall system productivity (Barillet et al., 2006). Although dairy sheep selection breeding schemes have traditionally focused on the improvement of milk production traits, a selection emphasis on nonyield traits, such as morphological and health-related traits, has been observed in recent years (Barillet, 2007).

In dairy sheep, the most important functional traits are those related to mammary morphology (Marnet and McKusick, 2001), although body conformation traits could be equally important because they are related to overall productivity and flocklife. Body conformation traits are also relevant when establishing a morphological breed standard with visual conformation appraisal, which is most likely the oldest method of information collection for the purpose of selection in many sheep breeding associations (Janssens and Vandepitte, 2004). In dairy cattle, body conformation traits are considered in breeding schemes as indicators of longevity because of moderate positive correlations between traits. Type traits, especially those describing feet and leg conformation, have been reported to show positive correlations with functionally productive life (Vukasinovic et al., 1995; Caraviello et al., 2004). Stature and body depth may influence feed intake and thus milk production in lactating animals (Veerkamp, 2002; Barillet, 2007).

The aforementioned points support the consideration of these traits as selection parameters in dairy sheep. In addition, due to the moderately positive genetic and phenotypic correlations between total body score and udder conformation traits described in dairy cattle (Brotherstone, 1994), it would be expected that ewes with high general body scores would also have wellformed udders.

Linear body conformation traits in meat sheep have shown medium to high heritability estimates $\left(h^{2}=0.26-\right.$ 0.57; Janssens and Vandepitte, 2004). In Churra dairy sheep, a preliminary estimation of genetic parameters for linear body conformation traits $\left(h^{2}=0.14-0.24\right)$ has also suggested that a significant improvement of these 
traits can be obtained by classical breeding (L. F. de la Fuente, unpublished results).

On the other hand, studies based on molecular markers can identify chromosomal regions with potentially important major genes that regulate economic traits, or QTL, in livestock species. The information derived from these studies may, in the future, be incorporated into genetic evaluations and selection indexes. Based on this, several studies have attempted to detect nonproduction QTL in dairy cattle (Spelman et al., 1999; Schrooten et al., 2000; Ashwell et al., 2001, 2005; Boichard et al., 2003; Hiendleder et al., 2003), although to a lesser extent when compared with classical production traits (reviewed by Khatkar et al., 2004; http://www.vetsci. usyd.edu.au/reprogen/QTL_Map/). In dairy sheep, genome scans have been undertaken to detect QTL related to milk production traits (Gutiérrez-Gil et al., 2009a; Raadsma et al., 2009), SCC (Gutiérrez-Gil et al., 2007), udder conformation traits (Casu et al., 2003; Gutiérrez-Gil et al., 2008b), and parasite resistance (Ellis et al., 2008; Gutiérrez-Gil et al., 2009b), whereas, to date, no QTL have been reported for body conformation in this species. Hence, as a first step toward the identification of genes associated with these traits in dairy sheep, the present study aimed to perform a genome scan for 5 body conformation traits considered in the current selection scheme of Churra dairy sheep.

\section{MATERIALS AND METHODS}

\section{Animals and Phenotypes}

A data set containing 10,189 records of 5 linear-type traits related to body conformation of 3,977 adult sheep daughters of 268 sires, belonging to 23 commercial flocks, was used in this study. These traits are scored at the same time as udder conformation traits and hence, only lactating ewes in a flock were scored in each evaluation visit. The age of the ewes included in this assessment ranged between 1.5 and 5 yr. From the whole data set, 4,932 ewes were of first parity, 697 of second parity, 586 of third parity, 545 of fourth parity, 113 of fifth parity, and 863 of sixth or greater parity. Most of the Churra flocks follow a production system based on 1 lambing per year and some have 3 lambings every 2 yr. This would explain the average of 2.6 scores per ewe in our data set. About $58 \%$ of the ewes were scored in 2 successive lactations. According to this routine body scoring system, the number of scores per ewe during her productive life ranged between 4 and 10 .

Different flocks were genetically connected via AI and all animals were part of the Churra sheep breed open nucleus scheme. The linear traits analyzed included 4 single traits (stature, rear legs-rear view, foot angle, and rump width) and one composite (general appearance body score). These traits, which are used to assess body conformation in Churra sheep (de la Fuente et al., 2003), were evaluated bimonthly in the 23 flocks for 24 consecutive months based on a linear scale ranging from 1 to 9 , where these values represent the biological extremes and 5 would be the median value in the considered population (see de la Fuente et al., 2003, the Appendix, and Figure 2 for a detailed description and a graphical representation of the scoring procedure of the traits). Briefly, stature and rump width are related to size and body capacity and are indicators of the skeletal development of the animal. Foot angle and rear legs-rear view correspond to the locomotion-type traits of the animal, whereas the composite general appearance assesses the general structure of the ewe compared with the prototype considered ideal in the Churra dairy breed. All flocks assessed for body conformation traits were registered in the official milk recording scheme organized by the local government. The descriptive statistics of the body conformation traits analyzed herein are shown in Table 1.

From the aforementioned database, animals belonging to half-sib families with at least 20 ewes were selected for this study, avoiding the analysis of very small families. Hence, following a daughter experimental design, 739 ewes from 11 half-sib sire families were included in the genome scan analysis reported here. For these 11 sire families, which were distributed over 17 different flocks linked by AI, the number of ewes per ram ranged from 30 to 148, with an average family size of 67 .

\section{Genotyping and Linkage Maps}

As the DNA source, blood samples were collected from ewes, whereas semen was collected from the sires. The DNA extraction protocols followed were those described by García-Fernández et al. (2009). In total, 181 microsatellite markers were analyzed across the whole resource population. The markers were amplified using the multiplex-PCR technique, as described previously by Gutiérrez-Gil et al. (2007, 2009a). The linkage map used in the QTL analysis has been described previously (Gutiérrez-Gil et al., 2008a). The average information content across this linkage map was 0.57 , ranging from 0.21 to 0.92 (Gutiérrez-Gil et al., 2009a).

\section{QTL Analyses}

The QTL analyses were performed using the HSQM package (version 6; Coppieters et al., 1998; Harmegnies et al., 2006), which applies the multi-marker regression method for half-sib designs described by Knott et al. (1996). The quantitative measurements used in this 
analysis were the yield deviations (YD) (VanRaden and Wiggans, 1991). The computation of YD was conducted with univariate animal repeatability models. Specific fixed effects considered were the flock-date-ofvisit effect ( $F D V, 238$ levels), DIM (7 levels), and age of the ewe at lambing ( $A G E, 6$ levels). The YD of animal $l$ was computed using the following equation:

$$
Y D_{l}=\frac{\sum_{1}^{n_{l}} y_{i j k l}-\widehat{F D V}_{i}-\widehat{D I M}_{j}-\widehat{A G E}_{k}-\hat{p}_{l}}{n_{l}},
$$

where $y_{i j k l}$ is the raw phenotypic record obtained during body conformation evaluation, $n_{l}$ is the number of testday records measured for each animal $l$, and $\hat{p}_{l}$ is the prediction of the permanent environmental effect for animal $l$. The inclusion of the parity number factor in the model was initially considered. However, when both factors were included in the model, age at lambing explained a larger proportion of the phenotypic variance than parity. Furthermore, because Churra sheep flocks, in general, follow a 1-lambing-per-year production system, these 2 factors are highly correlated. Hence, the factor $A G E$ was considered to include the factor parity number and at the same time accounts for the productivity stress accumulated during the animal's lifetime. The YD were calculated based on 10,189 records for 3,977 Churra ewes for which body morphological records were available. Although only 739 of these ewes had been genotyped for the markers, the complete database of animals with body trait measurements was used in the estimation of YD.

Following Churchill and Doerge (1994), 10,000 permutations of the phenotypic data across the genome were performed to obtain genome-wide $P$-values $\left(\boldsymbol{P}_{\mathbf{g}}\right)$ for the tests conducted. The QTL effects were considered significant if they exceeded the $5 \%$ genome-wise significance threshold $\left(P_{\mathrm{g}}<0.05\right)$. The suggestive significance level for which a single false positive is expected in a genome scan (Lander and Kruglyak, 1995) was also considered. Following Harmegnies et al. (2006), QTL were considered suggestive if the test statistic exceeded a threshold reached, on average, once per phenotype permutation. Assuming that the threshold exceeding events are distributed according to a Poisson distribution, the $P$-value corresponding to the suggestive threshold also corresponds to the proportion of permutations for which the suggestive threshold is exceeded at least once across the genome, which is $1-0.37=0.63$ (Harmegnies et al., 2006). Therefore, QTL were considered suggestive if $P_{\mathrm{g}}<0.63$. To graphically present results, statistical significance across the genome was expressed as $\log (1 /$ $\left.P_{\mathrm{g}}\right)$, and, therefore, the significance levels considered correspond to $\log \left(1 / P_{\mathrm{g}}\right)=1.3(5 \%$ genome-wise significance level) and $\log \left(1 / P_{\mathrm{g}}\right)=0.2$ (suggestive significance level). Chromosome-wise $P$-values $\left(\boldsymbol{P}_{\mathbf{c}}\right)$ estimated by permutation testing and $95 \%$ bootstrapping CI for the QTL positions (Visscher et al., 1996) were also obtained with the HSQM package.

When a significant or suggestive QTL was identified at the whole-population level, within-family analyses for the corresponding trait-chromosome combination were used to identify the segregating families for that QTL $\left(P_{\mathrm{c}}<0.05\right)$ and to estimate the QTL allelic substitution effect. The power of the experiment to detect a QTL of 0.3 phenotypic standard deviation units and 2 alleles at equal frequency, affecting a trait with a heritability of 0.2 (considering the average of the estimates given by L. F. de la Fuente, unpublished results) was estimated to be $29 \%$. Power calculations were as in Gutiérrez-Gil et al. (2009a).

\section{RESULTS}

Results from the genome-wise across-family regression analysis for the 5 body conformation traits analyzed here are depicted in Figure 1, where the statistical significance obtained for each centimorgan (Haldane) across the genome was represented as $\log \left(1 / P_{\mathrm{g}}\right)$. None of the QTL reached the $5 \%$ genome-wise significance threshold $\left[\log \left(1 / \mathrm{P}_{\mathrm{g}}\right)>1.3\right]$, whereas 7 suggestive linkage associations were identified $[\log (1 / \mathrm{Pg})>0.2$; Figure 1]: rump width on Ovis aries (OAR) $2(44 \mathrm{cM})$, stature and foot angle on OAR5 (82 and $104 \mathrm{cM}$, respectively), rear legs-rear view on OAR16 $(70 \mathrm{cM})$, rear legs-rear view and foot angle on OAR23 (2 and $13 \mathrm{cM}$, respectively), and stature on OAR26 (47 cM). As a reference, chromosome-wise statistical values $\left(P_{\mathrm{c}}<0.05\right)$ for these suggestive associations are indicated in Table 2. No QTL were suggested for general appearance.

The most significant linkage association, at the chromosome level, was detected in the second half of OAR16 for rear legs-rear view $\left(P_{\mathrm{c}}=0.006\right)$, between markers BMS2361 and AGLA29. The CI for this suggestive QTL spanned a 46-cM interval $(60-106 \mathrm{cM})$, whereas the CI estimated for the rest of the suggestive QTL involved larger intervals (Table 2). For the OAR16 QTL, 3 segregating families (Table 2) were identified (families 1, 3, and 11). Three other families were found to segregate for the QTL influencing the rear legs-rear view trait on OAR23. For the rest of the suggestive linkage associations reported here, 1 or 2 segregating families were identified (Table 2). In general, the positions estimated for the suggestive QTL identified in the across-family analysis were in agreement with those obtained for the segregating families in the within-family analyses. In a few cases, segregating families showed the maximum statistical value in a different chromo- 
Table 1. Basic statistics of the raw phenotypes assessing body conformation traits in the commercial population of Churra dairy sheep analyzed in this study; traits were scored on a 1-9 scale

\begin{tabular}{lcccc}
\hline Trait & $\mathrm{n}$ & $\begin{array}{c}\text { Arithmetic } \\
\text { mean }\end{array}$ & $\mathrm{SD}$ & $\mathrm{CV}$ \\
\hline Stature & 10,189 & 5.17 & 0.71 & 13.73 \\
Rear legs-rear view & 10,189 & 5.18 & 1.20 & 23.21 \\
Foot angle & 10,189 & 4.77 & 1.45 & 30.40 \\
Rump width & 10,189 & 5.38 & 0.88 & 16.44 \\
General body score & 10,189 & 5.07 & 1.08 & 21.21 \\
\hline
\end{tabular}

somal location: family 2 for the OAR2 QTL affecting rump width, family 6 for the OAR23 QTL influencing rear legs-rear view, family 11 for the OAR23 QTL affecting foot angle, and family 7 for the OAR26 QTL affecting stature; Table 2). Allelic substitution effects of the suggestive linkage associations identified ranged between 0.620 phenotypic SD units (for the OAR2 QTL controlling rump width) and 1.880 phenotypic SD units (for the OAR5 QTL influencing foot angle). The magnitude effect of the OAR16 QTL influencing rear legs-rear view showed intermediate values in that range, with an average of 0.827 phenotypic SD units for the 3 segregating families.

\section{DISCUSSION}

To our knowledge, this is the first genome scan analysis described in dairy sheep for body conformation traits. Seven putative QTL influencing 4 out of the 5 traits analyzed were identified in a population of Spanish Churra dairy sheep, although none of them reached the genome-wise significance level. The most significant QTL identified in our analysis, at the chromosome level, mapped to sheep chromosome 16 and influenced the rear legs-rear view trait. Other putative QTL were identified on chromosomes 2, 5, 23, and 26 for rump width, stature, and foot-leg related traits, whereas no linkage association was identified for general body score.

Any interpretation of these results should take into account the relatively low power $(\sim 30 \%)$ estimated for the experimental design, as mentioned before. From the statistical point of view, as different authors have suggested, very stringent significance thresholds are not suitable for preliminary genome scans such as that described here (Lander and Kruglyak, 1995; Southey and Fernando, 1998; Weller et al., 1998). Hence, the significance categories proposed by Lander and Kruglyak (1995) were followed, according to which 7 linkage associations showed evidence of suggestive linkage. The lack of significant genome-wise QTL segregation for body conformation traits in the resource population studied here is very likely caused by the limited power of our experimental design to detect QTL of moderate effect
$(<30 \%)$. This is an inherent limitation of QTL studies performed on commercial populations, where the same alleles may not segregate in all families. However, the use of outbred populations for QTL mapping also offers interesting advantages as they are available quickly and cheaply, and may contain QTL alleles of direct relevance to the breeding program (Haley, 1999). Another important limitation of the present study is the inaccuracy of the estimated QTL positions, especially for those cases in which discrepancies between the across-family and within-family analyses were observed. In some cases, these discrepancies might be due to a segregating QTL different from those identified at the whole population level, although they are likely to be the result of differences in marker informativeness among segregating families. To deal with this limitation, which is inherent to linkage mapping studies performed in commercial populations, additional markers should be analyzed to increase the accuracy of the QTL mapping.

Another issue that can affect the power of a QTL mapping experiment is the accuracy of the estimation of the dependent variables used in the analysis. Following VanRaden and Wiggans (1991), YD for each animal were estimated based on animal model evaluations, which combine information from an animal and all relatives. In this regard, it should be mentioned that ewes included in the present study were scored several times, within and between lactations. More accurate YD estimations could have been obtained by splitting the permanent environmental effect into 2 components, the within-lactation and the across-lactation effects. However, the simplistic repeatability model employed here, which only accounts for an overall permanent effect, is probably suitable considering the structure of the analyzed data. In this regard the number of lactations per ewe was low (1.4), the percentage of animals that only had measures during one lactation was high $(\sim 60 \%)$, and only a maximum of 2 consecutive lactations per animal was considered.

The Churra half-sib families included in this study have been shown to segregate for different QTL influencing milk production traits, udder conformation, and resistance to disease (Gutiérrez-Gil et al., 2007, 2008b, 2009a,b). Although the number of highly significant 
QTL identified in this population is low (genome-wise significant QTL have only been identified for milk protein percentage and for an indicator of parasite resistance; Gutiérrez-Gil et al., 2009a,b), this population shows a relatively high level of genetic variability that has allowed the identification of several putative segregating QTL. Hence, Churra sheep could be considered a valuable resource population for the identification of genetic effects controlling traits of economic interest in dairy sheep.

Regarding the traits analyzed in the present study, it should be noted that, in dairy production, after yield objectives are reached, functional traits appear to mark differences in productivity and maintenance. In dairy cattle, body conformation traits have been considered of great importance as functional traits for several years because of their relationship with functionality and longevity (Caraviello et al., 2004; Forabosco et al., 2004), whereas in dairy sheep, few reported studies have focused on these non-production traits.

In Churra dairy sheep, a preliminary assessment of the genetic parameters has shown moderate to high heritability values for the 5 linear traits assessing body conformation (L. F. de la Fuente, unpublished results). Based on this, conformation traits have recently been included in the breeding scheme, representing $5 \%$ of the total merit index of proven Churra breed sires, as has been done with udder conformation traits. Furthermore, because of the high correlation between body conformation and longevity observed in cattle (Vukasinovic et al., 1995; Strapák et al., 2005), we expect that the inclusion of these traits in the breeding scheme of Churra sheep may help achieve an indirect improvement of longevity; low heritability estimates observed in Churra allow little optimism for direct genetic selection for this complex trait (El-Saied et al., 2005).

Overlapping QTL for the different traits analyzed in the present study were observed on OAR5, where QTL for foot angle and stature were found close to the central region of the chromosome, and on OAR23, where a QTL influencing rear legs-rear view and another for foot angle were mapped within the proximal end of the linkage map. Although these overlapping QTL could indicate the existence of a single pleiotropic QTL influencing different traits, the estimated genetic correlations between the corresponding pairs of traits are moderate to low $(-0.28 \pm 0.08$ and $-0.10 \pm 0.07$, respectively; L. F. de la Fuente, unpublished results) and therefore no inference may be made in this regard. In relation to previous QTL identified in Churra sheep, it is worth mentioning that in the same region of OAR26 that harbors the QTL influencing stature, a QTL for udder attachment was also found (Gutiérrez-Gil et al., 2008b). Further research will be needed to decipher the genuine relationship underlying these overlapping QTL.
Some interesting similarities were found when comparing results of the present study with previously reported QTL for body conformation traits in dairy cattle. The bovine chromosomal region orthologous to the region of the rump width QTL identified in OAR2 by our analysis, which corresponds to BTA8, has been found to carry a QTL for body depth (Hiendleder et al., 2003) and stature/size (Schrooten et al., 2000) in dairy cattle. Furthermore, marker HEL4, which maps close to MCM147, one of the flanking markers of the rump width OAR2 QTL reported here, has been associated with body length in an Angora goat population (Marrube et al., 2007). In dairy cattle, a QTL influencing heel depth has been reported to be linked to marker BM7247 (Boichard et al., 2003), which is close to the peak of the foot angle QTL identified in this study on OAR5. Schrooten et al. (2000) identified several QTL influencing leg and foot traits (rear leg set, foot diagonal, feet and legs) close to marker CSSM31, which is the distal marker flanking the 2 QTL identified in our resource ovine population in OAR23 for similar traits. Additionally, in that region of BTA24, QTL for other body conformation traits (body depth, body form composite index, calving ease, strength, chest depth) have been reported (Boichard et al., 2003; Ashwell et al., 2005). Marker CSSM43, which maps close to the stature QTL identified here in OAR26, has been associated in cattle with dairy form (Ashwell et al., 2001, 2005), fore udder attachment (Hiendleder et al., 2003), and calving ease (Ashwell et al., 2005). The concurrence of several QTL for related traits in orthologous regions between sheep and cattle supports the suggestive linkage association reported herein. Additionally, it suggests the possible segregation of common QTL influencing body conformation traits in dairy populations of these 2 ruminant species.

For the other suggestive QTL regions reported here, including the linkage association showing the highest test statistic identified in this work (the OAR16 QTL for rear legs-rear view), no analogous reports were found in dairy cattle. This highlights the importance of developing further research in ovine populations instead of trying to build up practical implementations based exclusively on observations of cattle populations. As shown by García-Fernández et al. (2011), genes showing a strong influence on quantitative traits in cattle may not be segregating in sheep populations.

Because of the preliminary nature of the results presented here and because of the kind of traits analyzed in this work, it is not possible to propose reliable candidate genes at this point of the research. At the same time, it is worth mentioning that the growth hormone receptor-coding gene, GHR, maps close to the putative QTL for rear legs-rear view identified on OAR16. How- 

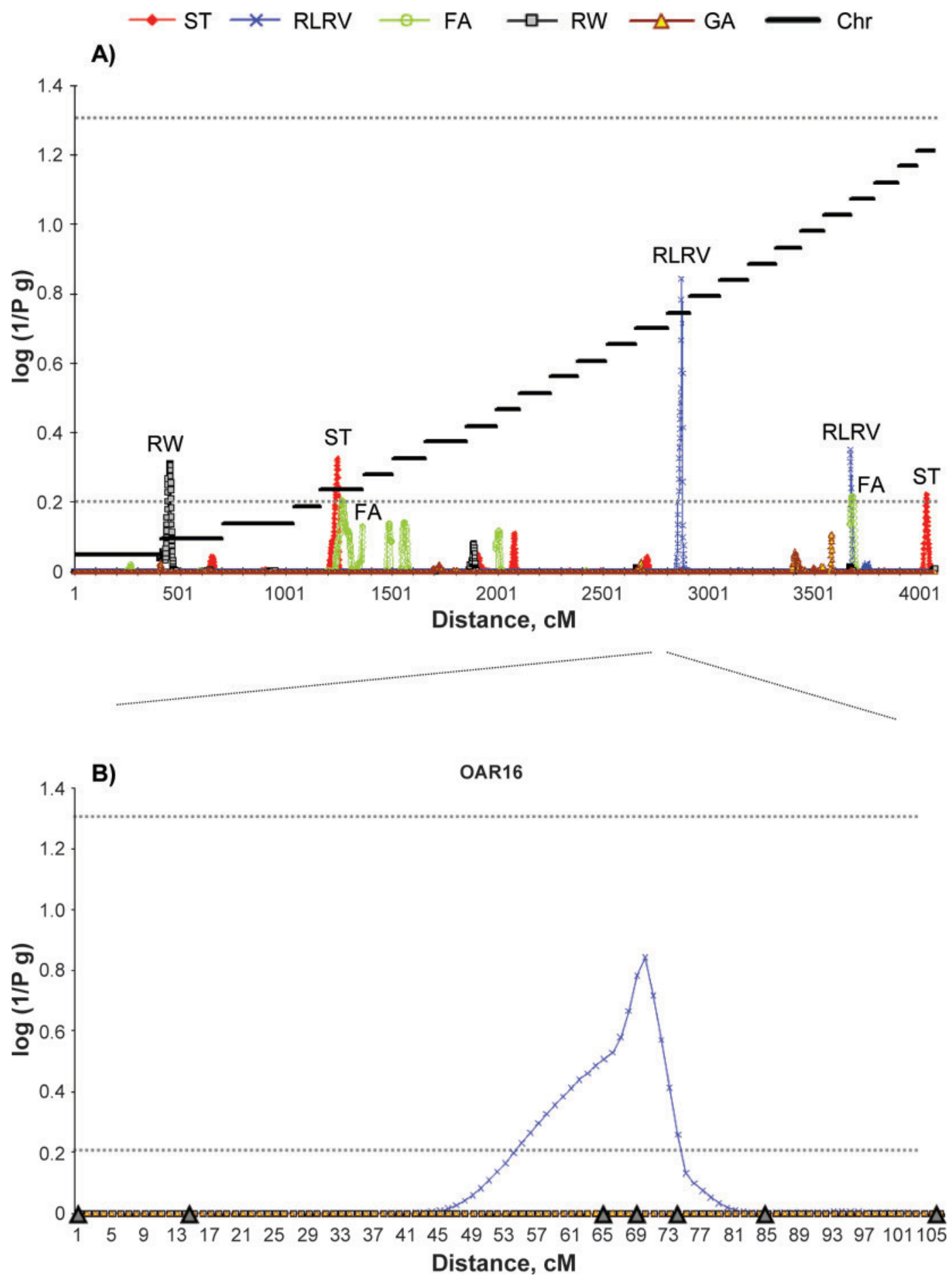

Figure 1. (A) Genome-wise statistical significance of the regression analysis carried out in Churra sheep for the 5 body conformation traits analyzed here: stature (ST), rear legs-rear view (RLRV), foot angle (FA), rump width (RW), and general appearance (GA). Statistical significance is expressed as $\log \left(1 / P_{\mathrm{g}}\right)$, where $P_{\mathrm{g}}$ is the proportion of the phenotypic permutation for which the QTL test statistic was exceeded anywhere across the genome. The black horizontal bars correspond to the 26 autosomes $(\mathrm{Chr})$ analyzed. The length of the linkage map is indicated in cM (Haldane) on the $x$-axis. The horizontal dashed lines indicate the suggestive $\left[\left(\log \left(1 / P_{\mathrm{g}}\right)<0.2\right]\right.$ and the $5 \%$ genome-wise significance thresholds $\left[\left(\log \left(1 / P_{\mathrm{g}}\right)<1.3\right]\right.$. (B) Results for ovine chromosome 16 (OAR16), for which the highest test statistic in this study was observed (rear legs-rear view). Beginning at the centromeric end, the triangles on the $\mathrm{x}$-axis indicate the relative position of the markers analyzed in this chromosome, which were RM106, BM1225, GHRLIV, BMS2361, AGLA29, MCM1, and MCM150. Color version available in the online PDF. 


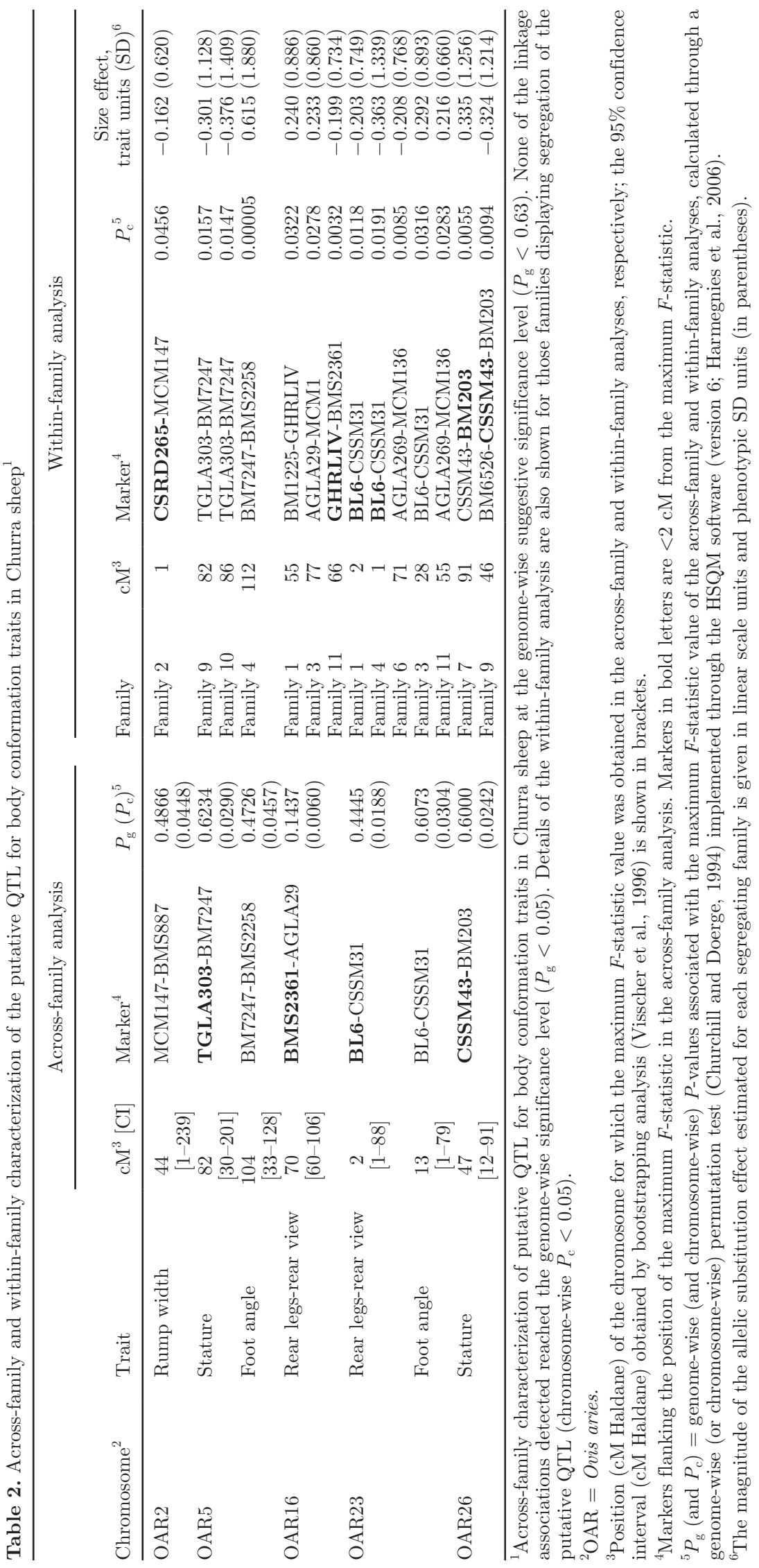


ever, before attempting further fine-mapping research efforts on some of the suggestive QTL regions reported herein, these should be confirmed with analysis of independent populations. An essential point for such confirmation studies will be the increase of the average family size and, hence, the statistical power to confirm and detect further QTL. Although a granddaughter design is known to provide increased power compared with a daughter design (Weller et al., 1990), the latter better fits the structure of the Churra population because the number of evaluated sires for these traits is reduced. Only after confirmation, further research could focus on increasing the marker density along the confidence intervals of the most promising QTL with the aim of identifying candidate genes in the corresponding chromosomal regions. In this regard, the recent assembly of the sheep genome (The International Sheep Genomics Consortium, 2010) and the high-throughput genotyping of SNP using the Illumina $50 \mathrm{~K}$ ovine SNP chip (Illumina Inc., San Diego, CA) may open up opportunities to better explore the genetic architecture of many of the QTL regions described previously in dairy sheep for different traits of economic interest.

This study provides the first account of a genome scan for detection of QTL influencing body conformation traits in dairy sheep. The regions revealed in the present analysis can be used as reference points for the development of genome-wide association analyses for body conformation traits in Churra sheep.

\section{ACKNOWLEDGMENTS}

This work was supported by a grant for research groups of excellence (Projects GR93 and LE008A08) from the Castilla and León regional government (Junta de Castilla y León) and the Spanish Ministry of Science (ProjectAGL2009-07000). Beatriz Gutiérrez-Gil is funded by the Juan de la Cierva Program of the Spanish Ministry of Science.

\section{REFERENCES}

Ashwell, M. S., D. W. Heyen, J. I. Weller, M. Ron, T. S. Sonstegard, C. P. Van Tassell, and H. A. Lewin. 2005. Detection of quantitative trait loci influencing conformation traits and calving ease in Holstein-Friesian cattle. J. Dairy Sci. 88:4111-4119.

Ashwell, M. S., C. P. Van Tassell, and T. S. Sonstegard. 2001. A genome scan to identify quantitative trait loci affecting economically important traits in a US Holstein population. J. Dairy Sci. 84:2535-2542.

Barillet, F. 2007. Genetic improvement for dairy production in sheep and goats. Small Rumin. Res. 70:60-75.

Barillet, F., J. M. Axtruc, and G. Lagriffoul. 2006. Functional traits in small dairy ruminants: Genetic variation and relationships with milk production. Page 02-01 in Proc. 8th World Congr. Genet. Appl. Livest. Prod., Belo Horizonte, MG, Brasil. Instituto Prociencia, Belo Horizonte, Brazil.

Boichard, D., C. Grohs, F. Bourgeois, F. Cerqueira, R. Faugeras, A. Neau, R. Rupp, Y. Amigues, M. Y. Boscher, and H. Levéziel. 2003.
Detection of genes influencing economic traits in three French dairy cattle breeds. Genet. Sel. Evol. 35:77-101.

Brotherstone, S. 1994. Genetic and phenotipic correlations between linear type traits and production traits in Holstein-Friesian dairy cattle. Anim. Prod. 59:183-187.

Caraviello, D. Z., K. A. Weigel, and D. Gianola. 2004. Analysis of the relationship between type traits and functional survival in US Holstein cattle using a Weibull proportional hazards model. J. Dairy Sci. 87:2677-2686

Casu, S., C. Marie-Etancelin, L. Schibler, E. Cribiu, L. Mura, T. Sechi, A. Fraghi, A. Carta, and F. Barillet. 2003. A genome scan to identify quantitative trait loci affecting udder morphology traits in dairy sheep. Commun. no. 2-19 in Proc. Int. Workshop Major Genes and QTL in Sheep and Goat (IWMGQSG), Toulouse, France. INRA-SAGA, Castanet Tolosan, France.

Churchill, G., and R. Doerge. 1994. Empirical threshold values for quantitative trait mapping. Genetics 138:963-971.

Coppieters, W., A. Kvasz, F. Farnir, J. J. Arranz, B. Grisart, M. Mackinnon, and M. Georges. 1998. A rank-based nonparametric method for mapping quantitative trait loci in outbred half-sib pedigrees: Application to milk production in a granddaughter design. Genetics 149:1547-1555.

de la Fuente, L. F., R. Alvarez, and E. J. Romo. 2003. La calificación morfológica en la raza Churra. Feagas 23:73-77.

El-Saied, U. M., L. F. De La Fuente, J. A. Carriedo, and F. San Primitivo. 2005. Genetic and phenotypic parameter estimates of total and partial lifetime traits for dairy ewes. J. Dairy Sci. 88:3265-3272.

Ellis, N. A., K. J. Fullard, S. A. Kayis, D. Khatkar, G. Attard, K. J. Beh, D. Piedrafita, and H. W. Raadsma. 2008. Fine mapping of QTL for parasite resistance in sheep. Poster 2006 in Proc. XXXI Conf. Int. Soc. Anim. Genet., Amsterdam, the Netherlands. International Society for Animal Genetics. http://www.isag.us/ Docs/2008_ISAG_Amsterdam_P2000.pdf.

Forabosco, F., A. F. Groen, R. Bozzi, J. A. M. Van Arendonk, F. Filippini, P. Boettcher, and P. Bijma. 2004. Phenotypic relationships between longevity, type traits, and production in Chianina beef cattle. J. Anim. Sci. 82:1572-1580.

García-Fernández, M., B. Gutiérrez-Gil, E. García-Gámez, and J. J. Arranz. 2009. Genetic variability of the stearoyl-CoA desaturase gene in sheep. Mol. Cell. Probes 23:107-111.

García-Fernández, M., B. Gutiérrez-Gil, J. P. Sánchez, J. A. Morán, E. García-Gámez, L. Álvarez, and J. J. Arranz. 2011. The role of bovine causal genes underlying dairy traits in Spanish Churra sheep. Anim. Genet. doi:10.1111/j.1365-2052.2010.02162.x.

Gutiérrez-Gil, B., J. J. Arranz, M. F. El-Zarei, L. Álvarez, S. Pedrosa, F. San Primitivo, and Y. Bayón. 2008a. A male linkage map constructed for QTL mapping in Spanish Churra sheep. J. Anim. Breed. Genet. 125:201-204.

Gutiérrez-Gil, B., M. F. El-Zarei, L. Alvarez, Y. Bayón, L. F. de la Fuente, F. San Primitivo, and J. J. Arranz. 2008b. Quantitative trait loci underlying udder morphology traits in dairy sheep. J. Dairy Sci. 91:3672-3681.

Gutiérrez-Gil, B., M. F. El-Zarei, L. Alvarez, Y. Bayón, L. F. de la Fuente, F. San Primitivo, and J. J. Arranz. 2009a. Quantitative trait loci underlying milk production traits in sheep. Anim. Genet. 40:423-434.

Gutiérrez-Gil, B., M. F. El-Zarei, Y. Bayón, L. F. de la Fuente, F San Primitivo, and J. J. Arranz. 2007. Genome scan analysis for detection of QTL influencing somatic cell score in dairy sheep. J. Dairy Sci. 90:422-426.

Gutiérrez-Gil, B, J. Pérez, L. Alvarez, M. Martínez-Valladares, L. F. de la Fuente, Y. Bayón, A. Meana, F. San Primitivo, F. A. Rojo-Vázquez, and J. J. Arranz. 2009b. Quantitative trait loci for resistance to trichostrongylid infection in Spanish Churra sheep. Genet. Sel. Evol. 28:41-46.

Haley, C. S. 1999. Advances in quantitative trait locus mapping. Pages 47-59 in From Jay Lush to Genomics: Visions for Animal Breeding and Genetics. J. C. M. Dekkers, S. J. Lamont, M. F. Rothschild, ed. AgBiotechNet, Ames, IA. 
Harmegnies, N., F. Davin, S. De Smet, N. Buys, M. Georges, and W. Coppieters. 2006. Results of a whole-genome quantitative trait locus scan for growth, carcass composition and meat quality in a porcine four-way cross. Anim. Genet. 37:543-553.

Hiendleder, S., H. Thomsen, N. Reinsch, J. Bennewitz, B. Leyhe-Horn, C. Looft, N. Xu, I. Medjugorac, I. Russ, C. Kühn, G. A. Brockmann, J. Blümel, B. Brenig, F. Reinhardt, R. Reents, G. Averdunk, M. Schwerin, M. Förster, E. Kalm, and G. Erhardt. 2003. Mapping of QTL for body conformation and behavior in cattle. J. Hered. 94:496-506.

Janssens, S., and W. Vandepitte. 2004. Genetic parameters for body measurements and linear type traits in Belgian Bleu du Maine, Suffolk and Texel sheep. Small Rumin. Res. 54:13-24.

Khatkar, M. S., P. C. Thomson, I. Tammen, and H. W. Raadsma. 2004. Quantitative trait loci mapping in dairy cattle: Review and meta-analysis. Genet. Sel. Evol. 36:163-190.

Knott, S. A., J. M. Elsen, and C. S. Haley. 1996. Methods for multiplemarker mapping of quantitative trait loci in half-sib populations. Theor. Appl. Genet. 93:71-80.

Lander, E., and L. Kruglyak. 1995. Genetic dissection of complex traits: guidelines for interpreting and reporting linkage results. Nat. Genet. 11:241-247.

Marnet, P. G., and B. C. McKusick. 2001. Regulation of milk ejection and milkability in small ruminants. Livest. Prod. Sci. 70:125-133.

Marrube, G., M. Cano, D. Rolda'n, F. Bidinost, M. Abad, D. Allain, D. Vaiman, H. Taddeo, and M. Poli. 2007. QTL affecting conformation traits in Angora goats. Small Rumin. Res. 71:255-263.

Raadsma, H. W., E. Jonas, D. McGill, M. Hobbs, M. K. Lam, and P. C. Thomson. 2009. Mapping quantitative trait loci (QTL) in sheep. II. Meta-assembly and identification of novel QTL for milk production traits in sheep. Genet. Sel. Evol. 22:41-45.

Schrooten, C., H. Bovenhuis, W. Coppieters, and J. A. Van Arendonk. 2000. Whole genome scan to detect quantitative trait loci for conformation and functional traits in dairy cattle. J. Dairy Sci. 83:795-806.

Southey, B. R., and R. L. Fernando. 1998. Controlling the proportion of false positives among significant results in QTL detection. Pages 221-224 in Proc. 6th World Congr. Genet. Appl. Livest. Prod., Armidale, Australia. Organizing Committee 6th World Congr. Genet. Appl. Livest. Prod., Armidale NSW, Australia.

Spelman, R. J., A. E. Huisman, S. R. Singireddy, W. Coppieters, J. J. Arranz, M. Georges, and D. J. Garrick. 1999. Short communication: Quantitative trait loci analysis on 17 nonproduction traits in the New Zealand dairy population. J. Dairy Sci. 82:2514-2516.

Strapák, P., P. Juhás, and V. Canji. 2005. The relationship between the body conformation to longevity in the Slovak spotted cows. Biotechnol. Anim. Husb. 21:53-59.

Archibald, A. L., N. E. Cockett, B. P. Dalrymple, T. Faraut, J. W Kijas, J. F. Maddox, J. C. McEwan, V. Hutton Oddy, H. W. Raadsma, C. Wade, J. Wang, W. Wang, and X. Xun. 2010. The sheep genome reference sequence: A work in progress. Anim. Genet. $41: 449-453$.

VanRaden, P. M., and G. R. Wiggans. 1991. Derivation, calculation, and use of national animal model information. J. Dairy Sci. 74:2737-2746.

Veerkamp, R. F. 2002. Feed intake and energy balance in lactating animals. CD-ROM communication 10-08 in Proc. 7th World Congr. Genet. Appl. Livest. Prod., Montpellier, France. INRA, CastanetTolosan, France.

Visscher, P. M., R. Thompson, and C. S. Haley. 1996. Confidence intervals in QTL mapping by bootstrapping. Genetics 143:1013-1020

Vukasinovic, N., J. Moll, and N. Künzi. 1995. Genetic relationships among longevity, milk production, and type traits in Swiss Brown cattle. Livest. Prod. Sci. 41:11-18.

Weller, J. I., Y. Kashi, and M. Soller. 1990. Power of daughter and granddaughter designs for determining linkage between marker loci and quantitative trait loci in dairy cattle. J. Dairy Sci. $73: 2525-2537$

Weller, J. I., J. Z. Song, D. W. Heyen, H. A. Lewin, and M. Ron. 1998. A new approach to the problem of multiple comparisons in the genetic dissection of complex traits. Genetics 150:1699-1706.

\section{APPENDIX}

A detailed description of the body confirmation traits measured in Spanish Churra sheep is given below, together with a graphical representation of the scoring system (Figure 2).

\section{Stature}

The stature of ewe is defined as the height to rump tallest point. This trait is closely related to the size of the animal. The greatest stature is assigned a score of 9 and the smallest 1 . In the Churra breed, the selection target is a medium size with a score of 5 .

\section{Rear Legs-Rear View}

This trait is defined as the vertical straightness of the rear legs. A score of 9 is the ideal and corresponds to completely straight legs. A score of 1, the least desired, depicts significant angulation, with hocks touching. This trait affects the animal's mobility and displacement.

\section{Feet Angle}

This trait is assessed by considering the angle formed by an axis that crosses the 3 phalanges of the hind hoof compared with the horizontal axis. A score of 9 (not desired) depicts more horizontal phalanges, whereas 1 corresponds to completely vertical phalanges. The ideal score is 5 .

\section{Rump Width}

This trait refers to the width of the hind quarters. The presence of fleece makes it difficult to assess visually. A score of 9 is given to the widest (most desirable) rump width and 1 to the narrowest. Rump width is important because it is associated with the width of the rest of the body, the pelvic canal included.

\section{General Body Score}

This is a composite trait describing the overall body conformation excluding udder. A score of 9 is the closest to the prototype considered ideal for the Churra ewe; namely, an animal with straight rear legs, a wide rump, and a straight back-lumbar line. In addition to the previously described 4 single traits, head, shoulder assembly, back, limbs, and equilibrium between the different parts of the body are also taken into account. The least desired score is 1 . 
Stature

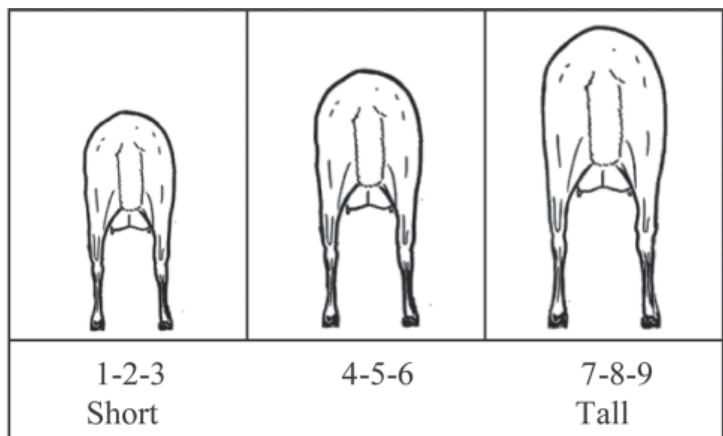

Rear legs (rear view)

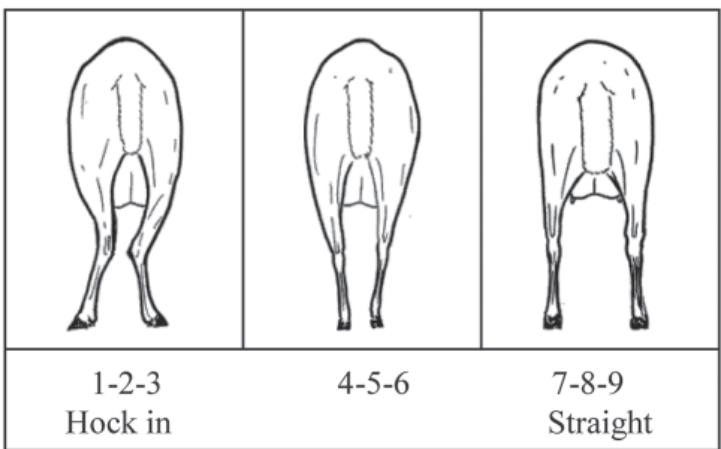

Feet angle

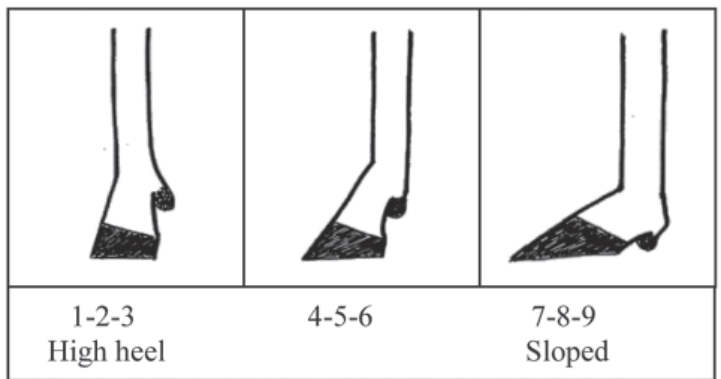

Rump width

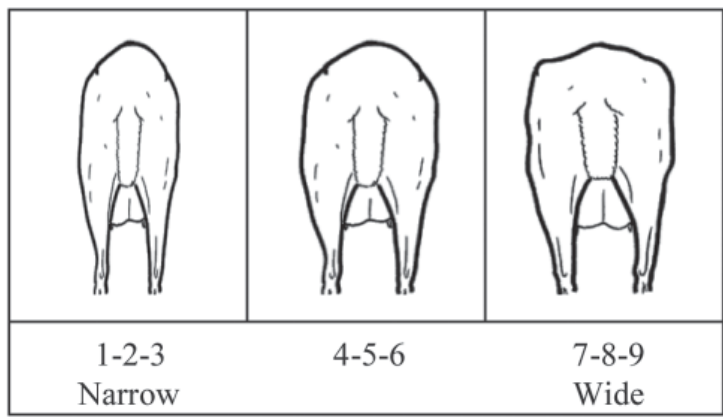

General body score

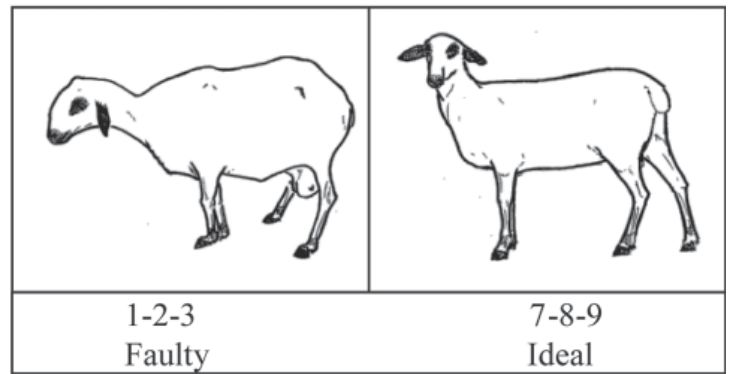

Figure 2. Linear scale system for body conformation traits score. 